Review

\title{
NF-אB in T-cell Acute Lymphoblastic Leukemia: Oncogenic Functions in Leukemic and in Microenvironmental Cells
}

\author{
Nuno R. dos Santos *, Marinella N. Ghezzo, Ricardo C. da Silva and Mónica T. Fernandes \\ IBB-Institute for Biotechnology and Bioengineering, Centre for Molecular and Structural Biomedicine \\ (CBME), University of Algarve, Campus de Gambelas, 8005-139 Faro, Portugal \\ * Author to whom correspondence should be addressed; E-Mail: nrsantos@ @ualg.pt (N.R.d.S.); \\ Tel.: +351-289-800-900 (ext. 7136); Fax: +351-289-818-419.
}

Received: 15 October 2010; in revised form: 3 November 2010 / Accepted: 4 November 2010 / Published: 5 November 2010

\begin{abstract}
Two main NF-אB signaling pathways, canonical and noncanonical, performing distinct functions in organisms have been characterized. Identification of mutations in genes encoding components of these NF- $\mathrm{B}$ signaling pathways in lymphoid malignancies confirmed their key role in leukemogenesis. T-cell acute lymphoblastic leukemia (T-ALL) is an aggressive malignancy of thymocytes that despite significant therapeutic advances can still be fatal. Although mutations in NF- $\mathrm{BB}$ genes have not been reported in T-ALL, $\mathrm{NF}-\kappa \mathrm{B}$ constitutive activation in human T-ALL and in acute T-cell leukemia mouse models has been observed. Although these studies revealed activation of members of both canonical and noncanonical NF- $\mathrm{BB}$ pathways in acute T-cell leukemia, only inhibition of canonical NF- $\kappa \mathrm{B}$ signaling was shown to impair leukemic $\mathrm{T}$ cell growth. Besides playing an important pro-oncogenic role in leukemic $\mathrm{T}$ cells, $\mathrm{NF}-\kappa \mathrm{B}$ signaling also appears to modulate $\mathrm{T}$-cell leukemogenesis through its action in microenvironmental stromal cells. This article reviews recent data on the role of these transcription factors in T-ALL and pinpoints further research crucial to determine the value of $\mathrm{NF}-\kappa \mathrm{B}$ inhibition as a means to treat T-ALL.
\end{abstract}

Keywords: NF-кB; signaling; T cell; leukemia; lymphoma; NOTCH1; microenvironment 


\section{Introduction}

Initially identified as regulators of immunoglobulin genes, the NF- $\kappa \mathrm{B}$ proteins have been found to be involved in multiple physiological and cellular processes. In addition, NF- $\kappa \mathrm{B}$ deregulation has been linked with a wide spectrum of human pathologies [1]. Germline or somatic alterations in human genes encoding either NF- $\mathrm{KB}$ proteins or upstream regulators have been identified in cancer, inflammatory conditions, immunodeficiencies, and skin and bone malformation syndromes. Several studies have uncovered key roles for $\mathrm{NF}-\kappa \mathrm{B}$ proteins in solid and hematological malignancies, turning this signaling pathway into a potential therapeutic target [2,3]. Recent findings have indicated that this is also true for T-cell acute lymphoblastic leukemia (T-ALL), as discussed in the present review. Although initially identified as activated in T-ALL cells, this signaling pathway can also contribute to leukemogenesis through its function in microenvironmental cells, as mentioned below.

\section{Canonical and Noncanonical NF-kB Activation Pathways}

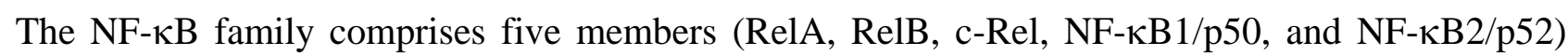
that combine as homo- or heterodimers to bind DNA and regulate transcription [4,5]. All family members contain the characteristic Rel homology domain (RHD), responsible for DNA binding, dimerization, and nuclear localization. The RelA (p65), RelB, and c-Rel subunits contain transactivation domains (TADs) that interact with transcriptional coactivators to control gene expression. The p50 and p52 proteins, which derive from proteolytic processing of the p105 and p100 precursor proteins, respectively, do not contain transactivation domains, and can only control gene transcription through dimerization with other NF- $\kappa \mathrm{B}$ subunits or interaction with other transcriptional regulators (e.g., Bcl3). In the steady-state the NF- $\kappa \mathrm{B}$ dimers are localized in the cytoplasm bound to inhibitory I $\mathrm{B}$ proteins. The I $\mathrm{KB}$ proteins $(\mathrm{I} \kappa \mathrm{B} \alpha, \mathrm{I} \kappa \mathrm{B} \beta, \mathrm{I} \kappa \mathrm{B} \varepsilon, \mathrm{p} 100, \mathrm{p} 105$, and $\mathrm{Bcl} 3)$ are characterized by the presence of an ankyrin repeat domain, which interacts with and inhibits the RHD domain of NF- $\kappa \mathrm{B}$ proteins. Thus, only when $\mathrm{I} \kappa \mathrm{B}$ proteins are degraded or proteolytically processed upon cell stimulation and I $\mathrm{B}$ kinase (IKK) activation, do NF- $\kappa \mathrm{B}$ factors translocate to the nucleus and become activated.

Two main NF- $\kappa \mathrm{B}$ pathways have been described that are activated by distinct stimuli, trigger distinctive transcriptional programs, and participate in diverse biological functions (Figure 1) $[4,5]$. The canonical pathway relies on the activation of the NEMO/IKK $\alpha / \mathrm{IKK} \beta$ kinase complex by tumor necrosis factor (TNF) $\alpha$ and other proinflammatory cytokines, Toll-like receptors, antigen receptors, DNA damage, among other signals, and is involved in biological processes such as cell survival, stress response, and inflammation. The IKK complex phosphorylates $\mathrm{I} \kappa \mathrm{B} \alpha, \mathrm{I} \kappa \mathrm{B} \beta$, or $\mathrm{I} \kappa \mathrm{B} \varepsilon$ on serine residues and earmarks these proteins for ubiquitination and proteasomal degradation. This pathway leads to activation of mainly RelA- or c-Rel-containing dimers. Despite the presence of IKK $\alpha$ in IKK complexes, gene inactivation studies have shown that only the NEMO regulatory subunit (also known as IKK $\gamma$ ) and the IKK $\beta$ catalytic subunit are required for canonical NF- $\kappa B$ activation [6-11]. Upon activation, RelA and c-Rel undergo serine phosphorylation at their TADs, allowing interaction with the CBP/p300 transcriptional co-activators, and transcriptional activation. Termination of canonical NF- $\kappa \mathrm{B}$ signaling occurs through different mechanisms acting at different levels (reviewed by Vallabhapurapu and Karin [5]). These include $\mathrm{I} \kappa \mathrm{B} \alpha$ re-synthesis with consequent export of RelA-containing dimers to the nucleus, ubiquitin-mediated RelA proteasomal degradation triggered by 
its phosphorylation by IKK $\alpha$ and implemented by SOCS1 and COMMD1 or PDLIM2 proteins, RelA displacement from DNA by PIAS proteins, and inactivation of the IKK complex or its upstream regulators by the A20 and CYLD deubiquitinating enzymes.

Figure 1. Schematic representation of the main actors intervening in the canonical and noncanonical NF- $\kappa \mathrm{B}$ activation pathways. Stimuli such as $\mathrm{TNF} \alpha$, lipopolysaccharide (LPS), interleukin-1 (IL-1), and major histocompatibility complex (MHC)-coupled antigen activate, through intermediary proteins, an IKK complex including the $\alpha$ and $\beta$ catalytic subunits and the NEMO regulatory subunit. Activation of this complex entails phosphorylation of $\mathrm{I} \kappa \mathrm{B} \alpha$ thus promoting its subsequent ubiquitination and proteasomal degradation. The nuclear localization signal present in the p50:RelA heterodimer becomes exposed, allowing its translocation to the nucleus and interaction with DNA target elements. The noncanonical pathway is activated by TNF family members such as BAFF, CD40, and lymphotoxin- $\alpha_{1} \beta_{2}$ and stabilizes and activates the NIK kinase through inhibition of intermediary proteins including TRAF2 and TRAF3. The NIK kinase has the ability to activate not only the noncanonical IKK $\alpha / \mathrm{IKK} \alpha$ complex but also the canonical IKK complex [26]. The IKK $\alpha$ complex phosphorylates p100 on C-terminal serines resulting in proteasomal degradation of p100 bound to p50:RelA and p50:RelB dimers or proteasomal processing of $\mathrm{p} 100$ bound to $\mathrm{p} 52$. This leads to nuclear translocation of p50:RelA, p50:RelB, and p52:RelB heterodimers, and regulation of their target genes.

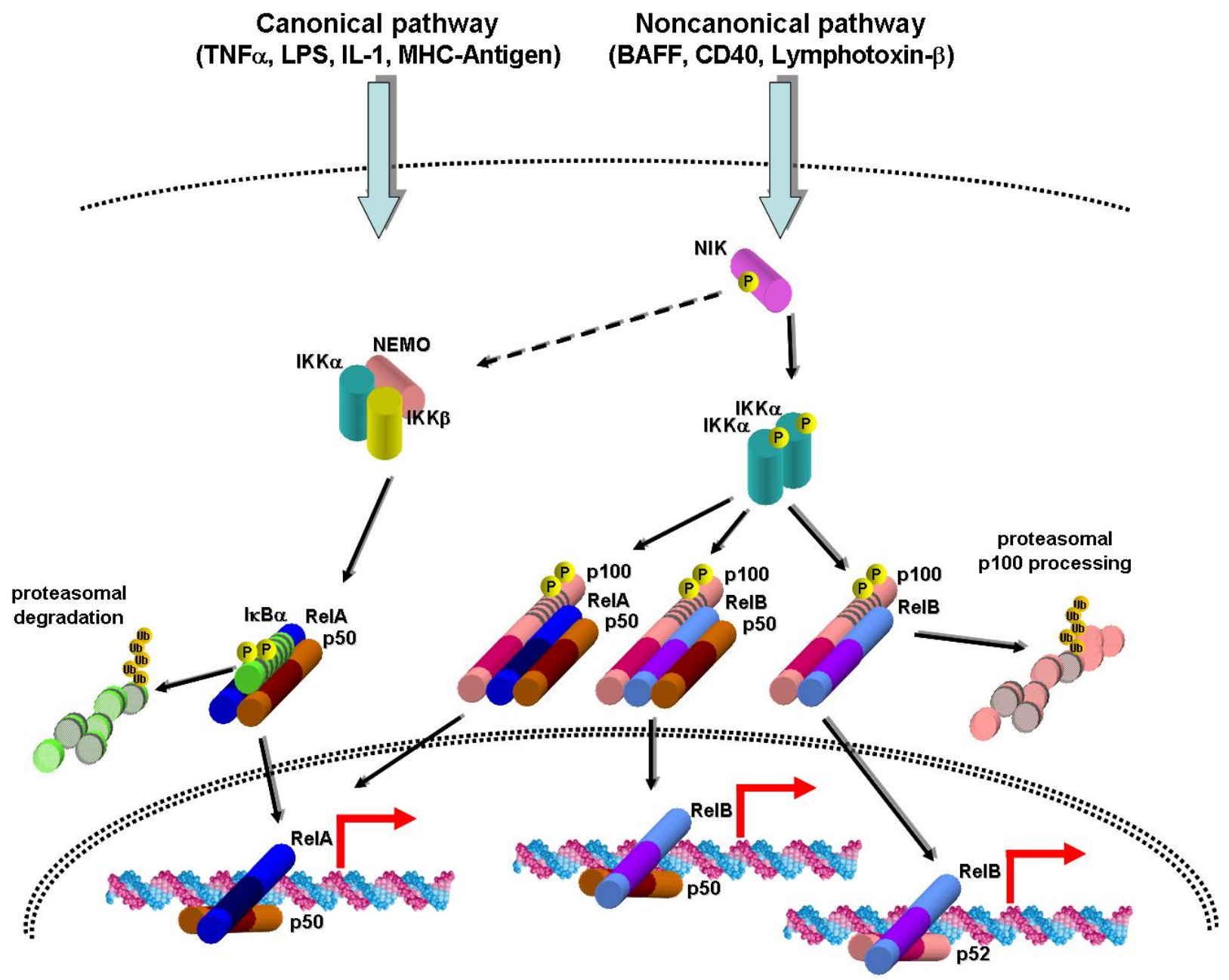


The noncanonical NF- $\kappa \mathrm{B}$ pathway, which is important for lymphoid organogenesis, B-cell maturation, and bone development, relies on the activation of the NF- $\kappa \mathrm{B}$-inducing kinase (NIK) and IKK $\alpha$ kinases by a subset of TNF $\alpha$-related receptors (e.g., BAFF, CD40, and LT $\beta R$ ). NIK is constitutively degraded by the proteasome through TRAF3-mediated ubiquitination by cIAP proteins. Upon receptor activation, TRAF3 and the associated TRAF2, cIAP1, and cIAP2 proteins are degraded, and NIK is stabilized [12-14]. Then NIK mediates recruitment of IKK $\alpha$ to p100 [15], and the latter is phosphorylated on serine residues and subsequently ubiquitinated and proteolytically processed to the p52 subunit. It was recently demonstrated that p100 functions (through its ankyrin repeat domain) as an inhibitor of several NF- $\mathrm{BB}$ dimers, including p50:RelA and p50:RelB [16,17]. Therefore, when p100 undergoes proteolysis, not only RelB- but also RelA-containing dimers are activated, although with slow kinetics, as compared to RelA heterodimers activated through the canonical pathway $[17,18]$. Studies using genetically deficient cells have indicated that NIK and IKK $\alpha$, but not NEMO and IKK $\beta$, are directly required for noncanonical NF- $\kappa B$ activation [16,18-20]. However, since expression of the RelB and p100 genes is induced by canonical NF- $\kappa \mathrm{B}[21,22]$, inactivation of this pathway also hampers noncanonical signaling [23]. As recently unraveled, noncanonical signaling can be terminated through the IKK $\alpha$-mediated phosphorylation of $\mathrm{COOH}$-terminal serines of NIK that promote its destabilization, through a TRAF3-independent mechanism [24].

The noncanonical activation of p50:RelA dimers by TNF-related receptors appears to occur through NIK/IKK $\alpha$-mediated p100 degradation (Figure 1) [17]. NIK may, however, activate RelA through other mechanisms. In lymphoid cells, NIK was shown to be required for $\mathrm{I} \kappa \mathrm{B} \alpha$ phosphorylation induced by the TNF family receptors CD27, CD40, and BAFF-R, but not by TNF $\alpha$ itself [25]. Activation of canonical NF- $\kappa \mathrm{B}$ by TNF-related receptors appears to involve NIK-mediated recruitment of the IKK $\alpha / \mathrm{IKK} \beta / \mathrm{NEMO}$ complex to these receptors and its subsequent activation [25]. Another study showed that increased $\mathrm{I} \kappa \mathrm{B} \alpha$ phosphorylation in Traf3-deficient mouse embryonic fibroblasts was dependent on NIK protein stabilization [26]. Although these data pointing to NIK activation by canonical NF- $\kappa B$ signaling may not reflect physiological settings, they are relevant in pathological situations when NIK is constitutively stabilized (see below).

\section{NF-kB Activation in Leukemia and Lymphoma}

Both canonical and noncanonical NF- $\kappa \mathrm{B}$ activation through different mechanisms has been reported in several types of human hematological malignancies, chiefly lymphoid leukemia and lymphoma (reviewed by Jost and Ruland [27] and Packham [28]). Constitutive NF- $\kappa \mathrm{B}$ activation often results from rearrangements and mutations in $\mathrm{NF}-\kappa \mathrm{B}$ genes or in genes encoding upstream components of the signaling pathway. Initial reports described chromosomal deletions or translocations leading to NFKB2 gene rearrangements in cutaneous T-cell lymphoma, B-cell non-Hodgkin lymphoma, chronic lymphocytic leukemia, and multiple myeloma [27,28]. More recently, genetic alterations in components of the noncanonical and canonical NF- $\kappa B$ pathways have been identified in a significant number of multiple myeloma cases [29,30]. Indeed, gain-of-function alterations were found in the NFKB1, NFKB2, NIK, CD40, LTBR, and TACI genes. In other cases, loss-of-function mutations were found in the TRAF2, TRAF3, CYLD, and BIRC2/BIRC3 genes, which encode negative regulators of $\mathrm{NF}-\kappa \mathrm{B}$. Several of these mutations were found in genes encoding regulators of the noncanonical 
NF- $\kappa \mathrm{B}$ pathway, including NIK, the NIK-activating CD40, TACI, and LT $\beta$ R receptors, and members of the complex that interacts with NIK and triggers its proteasomal degradation (i.e., TRAF2, TRAF3, BIRC2/cIAP1, and BIRC3/cIAP2) [13,14]. However, not only noncanonical but also canonical NF- $\mathrm{B}$ activity was found to be increased in multiple myeloma samples [29]. Consistently, IKK $\alpha$ and IKK $\beta$ inhibitory studies showed that IKK $\beta$-mediated canonical NF- $\kappa B$ signaling is important for multiple myeloma cell proliferation and survival [29,31]. Mutations in genes encoding NF- $\kappa \mathrm{B}$ regulators were also found in the activated B-cell-like subtype of diffuse large B-cell lymphomas, including mutations inactivating the NF- $\mathrm{BB}$ negative regulator A20/TNFAIP3 and mutations activating the CARD11, TRAF2, TRAF5, TAK1, and RANK positive regulators of NF- $\kappa \mathrm{B}$ [32-34].

$\mathrm{NF}-\kappa \mathrm{B}$ activation in leukemia/lymphoma may also derive from other mechanisms such as persistent autocrine or paracrine signaling. For example, ligand-independent signaling from overexpressed CD30 [35], CD40 stimulation by paracrine ( $\mathrm{T}$ cell-derived) CD40L stimulation [36], or autocrine RANK, BAFF, or APRIL stimulation [37-39]. Oncogenic kinase activity can also activate NF- $\kappa \mathrm{B}$ in leukemia, as demonstrated for BCR-ABL [40-42] and TEL-PDGFR $\beta$ fusion proteins [43]. Finally, proteins from viral strains associated with hematological malignancies (e.g., Epstein-Barr virus and human T-lymphotropic virus type 1) have the ability to activate canonical and noncanonical NF- $\mathrm{B}$ pathways [27,28].

\section{Molecular Pathogenesis of T-cell Acute Lymphoblastic Leukemia}

T-cell acute lymphoblastic leukemia (T-ALL) and T-cell lymphoblastic lymphoma (T-LBL) are aggressive malignancies of thymocytes that affect mainly children and adolescents. Although clinically distinct, T-ALL and T-LBL are often grouped together due to their similar morphological, genetic, and immunophenotypic features [44,45], and therefore will be referred to here simply as T-ALL. Being a thymocyte neoplastic disease, T-ALL seemingly originates in the thymus, at least in some cases. T-ALL patients frequently present high peripheral blast counts, central nervous system dissemination and larger mediastinal masses that cause tracheal compression and respiratory distress at diagnosis. Fortunately, current chemotherapeutic regimens can cure most pediatric and many adult patients, albeit with substantial secondary effects.

Several recurrent genetic alterations have been identified in human T-ALL [46-49]. Chromosomal translocations occur in about $20 \%$ of cases and result either in fusions between the coding regions of two genes, leading to chimeric protein expression, or in fusions between proto-oncogenes and T-cell receptor (TCR) loci, leading to oncogene overexpression (e.g., TAL1, TLX1, TLX3, HOXA, LMO1, and LMO2). One of the most frequent alterations in T-ALL (more than 50\% of cases) are NOTCH1 mutations, leading to activation of NOTCH1-dependent transcriptional programs [50]. Deletion or inactivating mutations in the CDKN2A gene occur in about $70 \%$ of cases, and these lead to loss or haploinsufficiency of its encoding proteins, the $\mathrm{p} 16^{\text {INK4a }}$ and ARF tumor suppressor proteins [51]. Although less frequently, other genetic alterations have been detected in T-ALL, including activating mutations in genes encoding the JAK1 [52], N-RAS [53], and FLT3 [54] signaling proteins, NUP214-ABL1 gene fusions [55], MYB gene duplications [56,57], inactivating mutations in $F B W 7$ (which encodes an ubiquitin ligase that triggers degradation of NOTCH1 among other proteins) [58], inactivating mutations and deletions in PTEN [59,60], LEF1 inactivation [61], PTPN2 deletions [62], 
and PHF6 mutations [63]. Activation of several signaling pathways, including PI3K/Akt, MAPK, JAK-STAT, and NF- $\kappa \mathrm{B}$ has also been reported in T-ALL (reviewed by Cardoso et al. [64] and Staal and Langerak [65]).

\section{NF-kB Activation in Human T-cell Acute Lymphoblastic Leukemia and T-cell Leukemia/Lymphoma Mouse Models}

Although mutations in NF- $\mathrm{BB}$ genes have not been reported in T-ALL, unlike other lymphoid malignancies, NF- $\kappa \mathrm{B}$ constitutive activation can occur in human T-ALL and mouse models of acute T-cell leukemia. NF- $\kappa$ B constitutive activation was initially detected by Kordes and colleagues [66], who detected NF- $\kappa \mathrm{B}$ activity in human T-ALL primary samples (11 of 13 cases) by electrophoretic mobility shift assays. Antibody supershift analysis identified p50:p50 homodimers and p50:RelA heterodimers activated in these cells. The T-ALL primary samples also presented phosphorylated I $\kappa \mathrm{B} \alpha$, indicative of canonical IKK activity. More recently, when analyzing a series of human T-ALL cell lines, Vilimas et al. [67] also found constitutive NF-кB DNA-binding activity. These investigators also detected constitutive IKK kinase activity and nuclear localization of the p50, p105, RelA, RelB, and c-Rel subunits in T-ALL cell lines. These data, together with findings that NF- $\kappa \mathrm{B}$ is constitutively activated in transgenic mouse models of T-ALL induced by Notch1, Notch3, Tal1, and TEL-JAK2 oncoproteins [68-71], indicate that NF- $\kappa \mathrm{B}$ activation occurs frequently in T-ALL leukemic cells. Furthermore, the reported RelB nuclear localization in T-ALL cell lines [67] suggests that not only canonical but also noncanonical NF- $\kappa \mathrm{B}$ activation can occur in T-ALL. However, this notion remains to be confirmed since increased p100 processing, the hallmark for noncanonical NF- $\kappa \mathrm{B}$ activation, is yet to be reported for this malignancy.

\section{NF-kB Inhibition in Human and Murine Leukemic T Cells}

To evaluate the impact of NF- $\mathrm{BB}$ activity on the leukemic phenotype of T-ALL, Vilimas et al. [67] treated human T-ALL cell lines with NF- $\kappa B$ canonical pathway inhibitors. Most cell lines treated with either BMS-345541, an IKK $\beta$ inhibitor, or bortezomib, a proteasome inhibitor, underwent apoptosis [67]. Furthermore, specific blockade of the canonical IKK complex with the NEMO-binding domain cell-permeable peptide inhibited NF- $\mathrm{NB}$ activity and led to apoptosis of T-ALL cell lines [71]. Apoptosis also occurred when NF- $\kappa \mathrm{B}$ was inhibited by $\mathrm{I} \kappa \mathrm{B} \alpha$ overexpression in a leukemic T-cell line derived from transgenic Notch3 mouse lymphoma [68]. In addition, murine leukemic T-cell lines resistant to chemotherapeutic agents and displaying constitutive NF- $\kappa \mathrm{B}$ activation underwent apoptosis upon treatment with BAY11-7086, an inhibitor of $\mathrm{I} \kappa \mathrm{B} \alpha$ phosphorylation [72]. Together, these studies indicate that canonical IKK/NF- $\mathrm{BB}$ signaling is essential for T-ALL cell viability. However, it remains to be verified whether primary patient samples are similarly sensitive to NF- $\mathrm{B}$ inhibition and whether noncanonical NF- $\mathrm{KB}$ signaling also plays a specific role in T-ALL cell survival or proliferation.

Although the impact of NF- $\mathrm{B}$ inhibition on human T-ALL growth in xenograft mouse models is yet to be investigated, T-cell leukemogenesis in mice engrafted with syngenic bone marrow progenitors transduced with intracellular NOTCH1 protein (ICN1) was shown to be impaired by either $\mathrm{T}$ cell-specific expression of an undegradable I $\mathrm{B} \mathrm{B} \alpha$ mutant $(\mathrm{I} \kappa \mathrm{B} \alpha \Delta \mathrm{N})$ protein [67] or hematopoietic 
lineage deletion of NEMO [71]. Based on blood cell counts and histological analyses, Vilimas et al. [67] concluded that impaired leukemogenesis by I $\mathrm{B} \alpha \Delta \mathrm{N}$ was due to reduced infiltration of several tissues by leukemic cells. The effects of NEMO deletion in the hematopoietic lineage on ICN1-mediated leukemogenesis appeared more drastic than those caused by $\mathrm{I} \kappa \mathrm{B} \alpha \Delta \mathrm{N}$ overexpression in the T-cell lineage. Upon NEMO deletion, mice having received Mx1-Cre-positive bone marrow progenitors retrovirally transduced with ICN1 presented reduced leukemic blasts in the blood, reduced spleen and liver infiltration, and increased leukemic cell apoptosis than NEMO-proficient controls [71]. These experiments unequivocally demonstrated that canonical IKK kinase activity is essential for Notch1-induced mouse T-ALL. However, since Mx1-Cre-mediated NEMO deletion inactivates NF- $\mathrm{B}$ in all hematopoietic cells, the possibility remains that NF- $\kappa \mathrm{B}$ inactivation in cells other than leukemic $\mathrm{T}$ cells may contribute to leukemogenesis, similarly to the role of inflammatory cells in carcinoma mouse models [73]. It would thus be interesting to verify whether NF- $\kappa \mathrm{B}$ activation in hematopoietic microenvironmental cells also contributes to T-ALL.

$\mathrm{NF}-\kappa \mathrm{B}$ inhibition in mice has, however, not always resulted in T-ALL regression. Indeed, despite being associated with constitutive NF- $\kappa \mathrm{B}$ activation, leukemogenesis driven by the TEL-JAK2 fusion protein was not prevented or weakened by expression of serine-mutated undegradable I $\mathrm{B} \alpha$ protein in the murine $\mathrm{T}$-cell lineage [69]. Likewise, $\mathrm{I} \kappa \mathrm{B} \alpha$ mutant expression in leukemic $\mathrm{T}$ cells derived from TAL1 transgenic mice, which present increased p50:RelA DNA-binding activity and NEMO-associated kinase activity, did not prevent tumor formation in syngenic recipient mice [70]. $\mathrm{I} \kappa \mathrm{B} \alpha$ mutant protein was functional in leukemic T cells from both TAL1 and TEL-JAK2 transgenic mice, because its expression effectively blocked NF- $\kappa \mathrm{B}$ activation induced by TNF $\alpha$ or phorbol

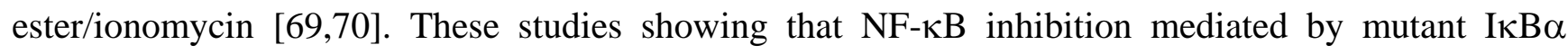
protein failed to impair T-cell leukemogenesis in two mouse models, hints that at least some subtypes of acute $\mathrm{T}$-cell leukemia may not require canonical $\mathrm{NF}-\kappa \mathrm{B}$ activation for its development or maintenance. However, one cannot exclude the possibility that NF- $\kappa \mathrm{B}$ activation in these mouse models either was not completely abolished by mutant $\mathrm{I} \kappa \mathrm{B} \alpha$ or it does not depend on $\mathrm{I} \kappa \mathrm{B} \alpha$ degradation, depending rather on an alternative mechanism of activation. Consistent with this notion, several studies indicate that NF- $\mathrm{KB}$ activity can be regulated by post-translational modifications of $\mathrm{NF}-\kappa \mathrm{B}$ or by interactions with other proteins [74].

\section{Paracrine/Autocrine Mechanisms of NF-kB Activation in T-ALL}

The mechanisms of NF- $\mathrm{BB}$ and IKK activation in T-ALL cells are beginning to be unveiled. In parallel to other lymphoid malignancies, these mechanisms may be intrinsic to neoplastic cells, due to mutations affecting the intracellular components of the NF- $\kappa \mathrm{B}$ pathway, as discussed in the following sections, or may depend on incoming microenvironmental cues. In normal T cells NF- $\kappa \mathrm{B}$ is activated by TCR or pre-T cell receptor (pre-TCR) signaling [75-77]. TCR stimulation by antigen results in oligomerization of the CARMA1, BCL10, and MALT1 (CBM) complex, which activates the IKK complex [5,78]. Although MALT1 and CARMA1 genetic alterations activating these proteins and activating NF- $\mathrm{KB}$ have been found in B-cell lymphomas [32,34,79,80], no mutations affecting the CBM complex in T-ALL have so far been reported. Since TCR overstimulation can be oncogenic [81], TCR expression could potentially favor leukemogenesis through NF- $\kappa \mathrm{B}$ activation, paralleling the 
recently discovered role of $\mathrm{B}$-cell receptor-mediated $\mathrm{NF}-\kappa \mathrm{B}$ activation in diffuse large B-cell lymphoma [82]. Although cell surface TCR expression appears to be infrequent in T-ALL samples and cell lines, about half of primary cases express cytoplasmic TCR chains [83,84]. In addition, several T-ALL cases express the pT $\alpha$ protein [83], which together with the TCR $\beta$ chain is an essential component of the pre-TCR complex. It is thus possible that TCR or pre-TCR expression drives NF- $\mathrm{B}$ activation in human T-ALL (Figure 2), although supporting evidence, at least in human cells, is lacking. TCR $\alpha$ deficiency in TEL-JAK2 transgenic mice led to a reduction in RelA DNA-binding activity in leukemic T cells [69]. However, this decrease in RelA activity was not associated with a delay in leukemia onset, suggesting that RelA was not essential for TEL-JAK2-induced disease [69]. Another study showed that pre-TCR expression was important for canonical NF- $\kappa$ B activation in leukemic $\mathrm{T}$ cells from transgenic Notch3 mice [85]. Supporting the notion that pre-TCR may drive NF- $\kappa \mathrm{B}$ activity in T-ALL, Vacca et al. [85] further showed that pT $\alpha$ deficiency attenuated the expression of NF- $\mathrm{KB}$ target genes putatively linked to the leukemic phenotype. In sum, these findings obtained with mouse models support the hypothesis that pre-TCR rather than TCR expression contributes to the activation of $\mathrm{NF}-\kappa \mathrm{B}$ in leukemic $\mathrm{T}$ cells.

\section{NF-kB Activation by NOTCH1 in T-ALL}

The NF- $\mathrm{B}$ signaling pathway can be potentially activated by oncoproteins expressed in T-ALL leukemic cells. NOTCH1 mutations found in human T-ALL result in increased levels of intracellular NOTCH1 protein and activation of NOTCH1-dependent transcriptional programs [86,50]. Several reports

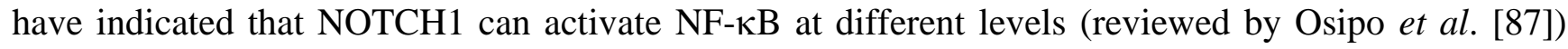
(Figure 2). Through its DNA-binding interaction partner CBF1/RBP-Jא, NOTCH1 was shown to bind the promoter and induce the expression of $N F K B 2$ and RELB in T-ALL cells $[67,88]$. In addition, ICN1 was shown to interact directly with and to retain p50 and c-Rel in the nucleus of activated splenocytes, thus preventing their sequestration by $\mathrm{I} \kappa \mathrm{B} \alpha$ and resulting in sustained NF- $\kappa \mathrm{B}$ activity [89]. Finally, NOTCH1 was shown to interact with and enhance IKK activity in T-ALL and cervical carcinoma cells [67,90]. Another mechanism for ICN1-induced IKK/NF- $\kappa B$ activation was recently uncovered by Espinosa et al. [71], who found that induction of the Hes1 transcriptional repressor by ICN1 in T-ALL cells led to CYLD downregulation and concomitant increased IKK activity. Endogenous Hes1 protein could bind the CYLD promoter in T-ALL cells, and the CYLD expression levels were found to be significantly decreased in most human primary T-ALL samples analyzed. This contrasted to HES1 expression, which was increased in these cells. The experiments performed by Espinosa and collaborators [71] in T-ALL and HEK293T cells support the notion that HES1-induced CYLD repression results in increased IKK kinase activity, I $\mathrm{B} \alpha$ degradation, RelA nuclear translocation, and NF- $\kappa \mathrm{B}$ transcriptional activity. No mutations in the CYLD gene were identified in T-ALL patients, indicating that in contrast to the multiple myeloma setting, where CYLD mutations were detected [29,30], this gene is inhibited at the transcriptional level. Finally, the finding that NOTCH1 inhibition in T-ALL cell lines by $\gamma$-secretase inhibitors (GSI) reduced the activity of both IKK [67] and an NF- $\kappa \mathrm{B}-$ dependent reporter [71] demonstrated the causative relationship between NOTCH1 mutations and IKK/NF- $\mathrm{KB}$ activity. 
Figure 2. Potential mechanisms of NF- $\kappa \mathrm{B}$ activation in T-ALL leukemic cells. TCR $\alpha \beta$ and pre-TCR cell surface complexes are known to activate NF- $\kappa \mathrm{B}$ in T cells and may do so in T-ALL as well, through constitutive signaling (pre-TCR) or MHC-coupled antigenic stimulation $(\mathrm{TCR} \alpha \beta)$. Intracellular NOTCH1 protein (ICN1) was shown to interact with and enhance IKK activity in T-ALL cells [67] and to interact with and stabilize p50:c-Rel heterodimers in the nucleus of activated splenocytes [89]. The ICN1-induced HES1 repressor facilitates NF- $\mathrm{\kappa B}$ activation by repressing the expression of the deubiquitinating enzyme CYLD [71], a negative regulator of the canonical NF- $\kappa B$ pathway. Together with $\mathrm{CBF}$ and co-activators (CoA), ICN1 may potentially facilitate noncanonical $\mathrm{NF}-\kappa \mathrm{B}$ activation by direct induction of the NFKB2 and RELB genes $[67,88]$.

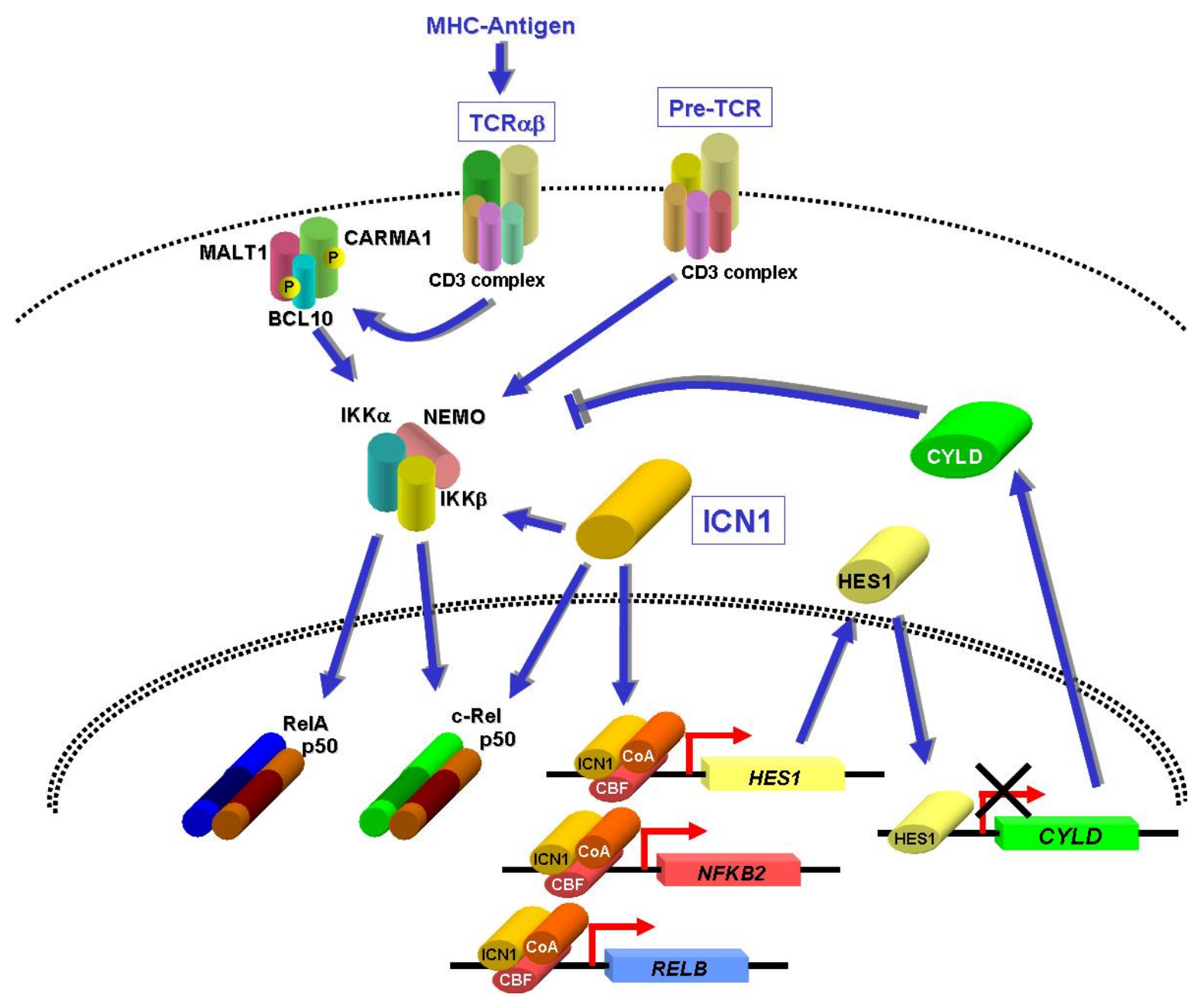

\section{NF-кB Activation by Other Oncoproteins?}

However important ICN1 may be for NF- $\kappa B$ activation, it is possibly not the sole means of activating these transcription factors in T-ALL. Genome-wide gene expression studies have led to the definition of molecular subgroups of T-ALL, characterized by the ectopic expression of particular proto-oncogenes (e.g., TAL1, LMO1, LMO2, TLX1, TLX3, and HOXA) and associated different disease prognosis (extensively reviewed by van Vlierbergh et al. [49]). Although no NF- $\kappa \mathrm{B}$ pathway gene signature was detected for the TAL1-positive subgroup, other work showed that TAL1 protein expression in T-ALL cells can control NF- $\kappa \mathrm{B}$ activity through direct NFKB1 promoter repression [91]. The lower 
steady-state p50 levels in T-ALL cell lines caused by TAL1 expression impaired p50:RelA dimer formation and increased c-Rel:RelA dimers when cells were exposed to etoposide, an NF- $\mathrm{BB}$-activating agent [91]. Etoposide-induced ICAM1 expression, a target of c-Rel:RelA heterodimers, was eliminated by antisense-mediated TAL1 knock-down, supporting the notion that transcriptional programs may be

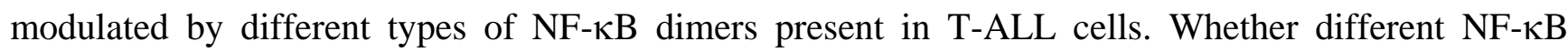
dimers are activated in different molecular subgroups of T-ALL should be investigated.

$\mathrm{NF}-\kappa \mathrm{B}$ transcription factors may be activated by other signaling pathways. Constitutive JAK2 kinase activity due to fusion with the TEL/ETV6 transcriptional repressor has been linked with human and murine B-cell and T-cell malignant transformation [92-96]. By an as yet undefined mechanism, TEL-JAK2 kinase activity was shown to activate IKK proteins and to induce NF- $\kappa$ B DNA-binding activity in the $\mathrm{Ba} / \mathrm{F} 3 \mathrm{~B}$-cell line [97,98]. Although leukemic T cells from TEL-JAK2 transgenic mice presented NF- $\kappa B$ DNA-binding activity [69] no evidence for a direct activation of NF- $\kappa B$ by this fusion protein in human or mouse leukemic $\mathrm{T}$ cells has so far been reported.

The possibility that NF- $\kappa B$ activation in T-ALL is caused by other genetic alterations found in this disease warrants investigation, especially concerning proteins known to regulate $\mathrm{NF}-\kappa \mathrm{B}$ in other settings. For example the $L C K$ gene has been found to be overexpressed due to rare chromosomal translocations involving the TCRB locus in T-ALL [99] and its kinase activity can activate NF- $\mathrm{B}$ in $\mathrm{T}$ cells [100]. Increased ABL1 kinase activity occurs in a subset of T-ALL patients due to the NUP214-ABL1 gene fusion [55], and another ABL1 fusion, BCR-ABL1, has been shown to activate $\mathrm{NF}-\kappa \mathrm{B}$ in myeloid leukemic cells [101,102]. Finally, PI3K/Akt pathway activation due to PTEN inactivation occurs in many T-ALL cases $[59,60]$ and this pathway has also been shown to activate NF- $\mathrm{B}$ in T lymphocytes [103]. Alterations in the MAP kinase ERK5 gene have not yet been reported in human T-ALL, but the ERK5 protein has been shown to be important for leukemic T cell survival and ability to grow in immunodeficient mice [104]. In addition, ERK5 was able to induce RelA nuclear localization and to activate an NF- $\mathrm{BB}$ reporter gene, through an uncharacterized mechanism independent of canonical IKK activation [104]. In sum, several molecular alterations may concurrently

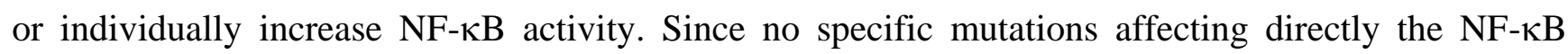
pathway have been detected in T-ALL, NF- $\mathrm{KB}$ is most likely activated by a combination of factors.

\section{NF-kB Function in Microenvironmental Cells of T-ALL}

Accumulating evidence indicates that cancer progression depends not only on alterations in cancer cells but also on microenvironmental factors [105]. Heterotypic signaling can occur in hematological malignancies [106], yet little is known about the microenvironmental factors participating in T-ALL. $\mathrm{NF}-\kappa \mathrm{B}$ activation in microenvironmental cells has been pinpointed as a key player in the genesis of a variety of cancers [73], and recent reports indicate that NF- $\mathrm{BB}$ activity in microenvironmental cells can also contribute to T-ALL pathogenesis. It was recently found that RelB deficiency in non-hematopoietic stromal cells impaired murine leukemogenesis driven by the TEL-JAK2 fusion protein [69]. Since T-cell leukemogenesis in the transgenic TEL-JAK2 mouse model, like human T-ALL, appears to originate from thymocytes [92,107], RelB-dependent thymic stromal cells are the most likely non-hematopoietic cells involved in this disease. RelB-deficient mice present subtle defects in the thymic microenvironment, such as absence of a defined medulla and absence of medullary thymic 
epithelial cells (mTEC) [108-110]. Compared to controls, RelB-deficient mice also present a strong reduction in $\mathrm{CD} 80^{+} \mathrm{DEC} 205^{+}$dendritic cell (DC) numbers, which was shown to be secondary to the defects in thymic architecture and mTECs [111]. Despite these thymic defects, thymocyte development up to the $\mathrm{CD} 4^{+} \mathrm{CD} 8^{+}$double-positive stage appeared unimpaired in RelB-deficient mice (combined with TCR $\alpha$ deficiency), indicating that the potential targets for TEL-JAK2-induced malignant transformation were not lacking [69]. These results have thus pinpointed a role for RelB in T-cell leukemogenesis through its activity in microenvironmental cells, presumably localized in the thymus.

The mechanisms through which RelB supports T-cell leukemogenesis remain blurred (Figure 3). CCR7 stimulation is a likely candidate, since its ligands CCL19 and CCL21 are induced by RelB-dependent noncanonical NF- $\kappa$ B signaling [112]. CCR7 expression was recently reported in human primary T-ALL and cell lines [113], and animal studies showed that CCR7 stimulation by its ligands was crucial for the targeting and infiltration of leukemic $\mathrm{T}$ cells to the central nervous system [113]. Regarding other potential mechanisms, no evidence has been raised indicating that RelB or other NF- $\kappa \mathrm{B}$ members induce NOTCH ligands or IL-7, which are important thymic microenvironmental and oncogenic factors in T-ALL [114-117]. Further investigation is thus warranted to identify the RelB-dependent microenvironmental molecular cues important for T-ALL development.

Figure 3. Microenvironmental signals assisting T-ALL leukemic cells. IL-7 produced by stromal cells was shown to induce survival and proliferation of T-ALL cells $[114,115]$. T-ALL cells were shown to express cognate receptors and to respond to CCL19/CCL21, CCL25 and CXCL12 chemokines, which are potentially induced by RelB [18]. CCR7 stimulation by CCL19 or CCL21 was shown to direct T-ALL cells to the mouse central nervous system [113]. CCR9 stimulation by CCL25 induced T-ALL chemotaxis and resistance to chemotherapy-induced apoptosis [127], while CXCR4 stimulation by CXCL12 also induced T-ALL chemotaxis [128]. Another study showed that the NOTCH3 ligand, Dll4, mediated T-ALL escape from tumor dormancy in mice [116]. Stromal cells expressing the ICAM1 adhesion molecule were shown to favor in vitro survival of T-ALL cells expressing LFA-1 integrin [129]. Whether the expression and/or function of these or other stromally produced proteins is controlled by RelB or other NF- $\kappa B$ subunits remains to be determined.

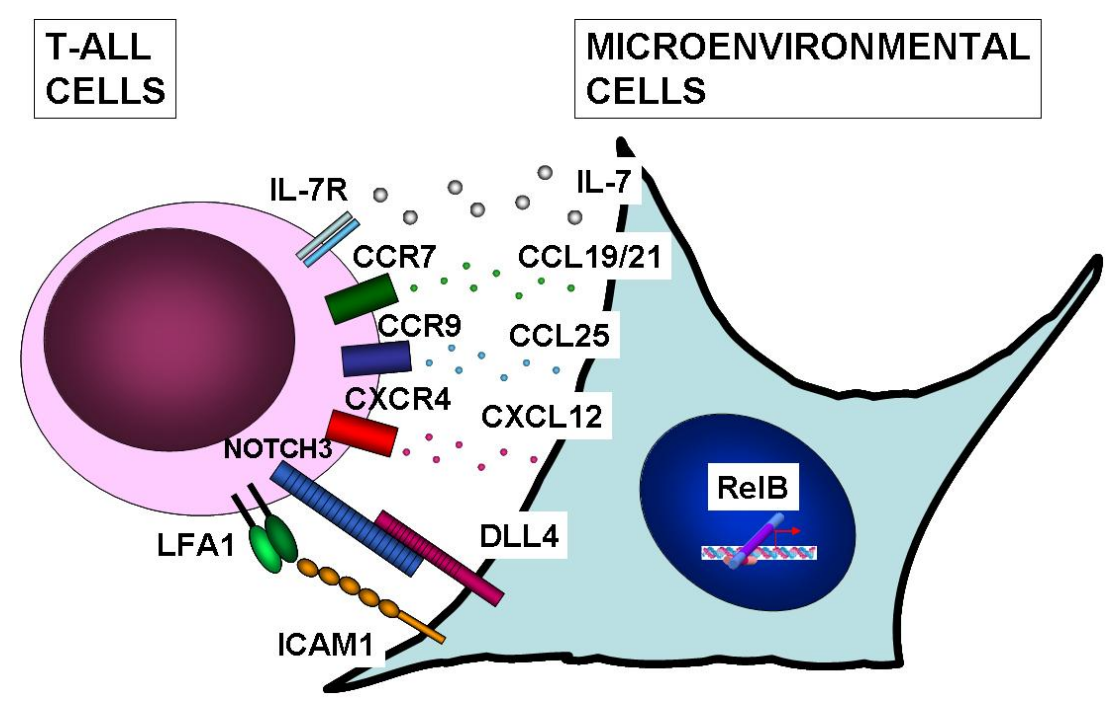




\section{NF-אB Inhibition as a Therapeutic Strategy for T-ALL?}

T-ALL patients are treated by multiagent chemotherapy protocols, that include glucocorticoids (e.g., prednisone or dexamethasone), anthracyclins (e.g., doxorubicin or daunorubicin), the alkaloid vincristine, asparaginase, alkylating agents (e.g., cyclophosphamide), and antimetabolites (e.g., nelarabine, cytarabine, mercaptopurine and methotrexate) [118]. Treatment with these compounds results in leukemic cell apoptosis [119]. In addition, several of these agents (e.g., vincristine, daunorubicin, doxorubicin, and cytarabine) are known to induce NF- $\kappa \mathrm{B}$ activation, due to their DNA damaging action $[120,121]$. NF- $\kappa \mathrm{B}$ activation in different cancers has been shown to confer resistance to chemotherapy-induced apoptosis [121]. Supporting the notion that constitutive NF- $\mathrm{B}$ activity indeed protects cancer cells from chemotherapy-induced apoptosis, several studies demonstrated that $\mathrm{NF}-\kappa \mathrm{B}$ inhibition through expression of the I $\mathrm{B} \alpha \alpha$ super-repressor mutant or pharmacological NF- $\kappa \mathrm{B}$ inhibitors rendered chemoresistant cancer cell lines sensitive to chemotherapeutic agent-induced apoptosis [121]. Moreover, anti-apoptotic NF- $\mathrm{KB}$ target genes, such as pro-survival Bcl2 family members and the IAP family of caspase inhibitors, were found to be expressed in chemoresistant cancer cell lines with constitutive NF-kB activation [121,122].

$\mathrm{NF}-\kappa \mathrm{B}$ activation may also confer chemoresistance to T-ALL cells. When Garcia et al. [72] compared murine leukemic T-cell lines resistant to vincristine or doxorubicin with the chemosensitive parental cell line, they found that the former presented higher constitutive NF- $\kappa \mathrm{B}$ activity. This suggested that higher NF- $\kappa \mathrm{B}$ activity could underlie chemoresistance in these cells. BAY11-7082mediated NF- $\kappa \mathrm{B}$ inhibition led to apoptosis of chemoresistant cell lines and abrogated resistance to vincristine or doxorubicin, indicating that this pathway is crucial for chemoresistance [72]. Another study showed that DNA damage induced by doxorubicin, etoposide, and other agents activated NF- $\mathrm{B}$ in the CEM T-ALL cell line [123]. These investigators also showed that NF- $\kappa B$ blockade by the I $\kappa \mathrm{B} \alpha$ super-repressor led to CEM apoptosis upon DNA damage induction, indicating that chemoresistance in

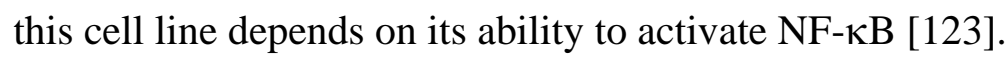

Although needing confirmation with primary samples, these reports indicate that $\mathrm{NF}-\kappa \mathrm{B}$ inhibitors (e.g., proteasomal or IKK $\beta$ inhibitors) can induce T-ALL apoptosis and can be of therapeutic value either as stand-alone therapy or as an additional tool to improve standard chemotherapy regimens currently in use. NF- $\kappa \mathrm{B}$ inhibitors may also be useful in combination with inhibitors of other signaling pathways activated in T-ALL, such as the NOTCH1 and mTOR pathways [124-126]. However, therapy using NF- $\mathrm{KB} / \mathrm{IKK} \beta$ inhibitors can only be envisaged when firm pre-clinical or clinical evidence that the canonical NF- $\kappa \mathrm{B}$ activation is important for the maintenance of human T-ALL in vivo is obtained.

\section{Conclusions}

As reviewed here, accumulating evidence obtained with different experimental models points to a role for NF- $\mathrm{B}$ signaling in T-ALL. Importantly, the pro-oncogenic roles of NF- $\kappa \mathrm{B}$ appear to be both intrinsic to leukemic $\mathrm{T}$ cells and mediated by microenvironmental cells. Several issues remain however to be elucidated. Different studies have provided evidence for both canonical and noncanonical NF- $\mathrm{B}$ activation in T-ALL cells, but it has not been clearly determined how these pathways impinge on the malignant features of T-ALL in vivo. This is not a minor issue since these pathways differ in terms of 
regulation, kinetics, and activated target genes. Furthermore, NF- $\kappa \mathrm{B}$ inhibitors currently being tested in clinical trials target the canonical pathway and may thus not be effective to block noncanonical $\mathrm{NF}-\kappa \mathrm{B}$ activity in T-ALL. Experiments aiming to inhibit either canonical or noncanonical NF- $\mathrm{B}$ signaling in animal models of human T-ALL using genetically inactivated alleles or RNA interference are warranted to address this issue. Such experiments should also shed light on the nature of NF- $\mathrm{B}$ target genes that contribute to the malignant phenotype.

How NF- $\mathrm{BB}$ activity in the T-ALL microenvironment participates in this disease is still unclear. It will be important to determine whether NF- $\kappa \mathrm{B}$ or RelB activity in microenvironmental cells is important throughout different stages of disease. If so, one can envisage T-ALL therapy through $\mathrm{NF}-\kappa \mathrm{B}$ inhibition in leukemia-associated microenvironmental cells. Normal microenvironmental cells are likely less prone to mutate and develop resistance to therapy than malignant cells.

\section{Acknowledgements}

This work was supported by IBB/CBME, LA, FEDER/POCI 2010, by Fundação para a Ciência e Tecnologia (PTDC/SAU-OBD/103336/2008), and by Núcleo Regional Sul da Liga Portuguesa Contra o Cancro (NRS/LPCC).

\section{References}

1. Courtois, G.; Gilmore, T.D. Mutations in the NF-кB signaling pathway: Implications for human disease. Oncogene 2006, 25, 6831-6843.

2. Bassères, D.S.; Baldwin, A.S. Nuclear factor- $\kappa \mathrm{B}$ and inhibitor of $\kappa \mathrm{B}$ kinase pathways in oncogenic initiation and progression. Oncogene 2006, 25, 6817-6830.

3. Karin, M. Nuclear factor- $\kappa \mathrm{B}$ in cancer development and progression. Nature 2006, 441, 431-436.

4. Hayden, M.S.; Ghosh, S. Signaling to NF-кB. Genes Dev. 2004, 18, 2195-2224.

5. Vallabhapurapu, S.; Karin, M. Regulation and function of NF- $\kappa \mathrm{B}$ transcription factors in the immune system. Annu. Rev. Immunol. 2009, 27, 693-733.

6. Hu, Y.; Baud, V.; Delhase, M.; Zhang, P.; Deerinck, T.; Ellisman, M.; Johnson, R.; Karin, M. Abnormal morphogenesis but intact IKK activation in mice lacking the IKK $\alpha$ subunit of IкB kinase. Science 1999, 284, 316-320.

7. Li, Q.; Van Antwerp, D.; Mercurio, F.; Lee, K.F.; Verma, I.M. Severe liver degeneration in mice lacking the IкB kinase 2 gene. Science 1999, 284, 321-325.

8. Li, Q.; Lu, Q.; Hwang, J.Y.; Büscher, D.; Lee, K.F.; Izpisua-Belmonte, J.C.; Verma, I.M. IKK1deficient mice exhibit abnormal development of skin and skeleton. Genes Dev. 1999, 13, 1322-1328.

9. Li, Z. W.; Chu, W.; Hu, Y.; Delhase, M.; Deerinck, T.; Ellisman, M.; Johnson, R.; Karin, M. The IKK $\beta$ subunit of I $\mathrm{B}$ kinase (IKK) is essential for nuclear factor $\kappa \mathrm{B}$ activation and prevention of apoptosis. J. Exp. Med. 1999, 189, 1839-1845.

10. Rudolph, D.; Yeh, W.C.; Wakeham, A.; Rudolph, B.; Nallainathan, D.; Potter, J.; Elia, A.J.; Mak,

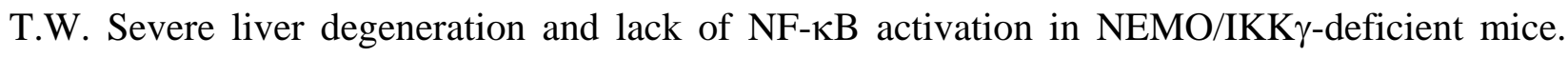
Genes Dev. 2000, 14, 854-862. 
11. Takeda, K.; Takeuchi, O.; Tsujimura, T.; Itami, S.; Adachi, O.; Kawai, T.; Sanjo, H.; Yoshikawa, K.; Terada, N.; Akira, S. Limb and skin abnormalities in mice lacking IKK $\alpha$. Science 1999, 284, 313-316.

12. Liao, G.; Zhang, M.; Harhaj, E.W.; Sun, S. Regulation of the NF-кB-inducing kinase by tumor necrosis factor receptor-associated factor 3-induced degradation. J. Biol. Chem. 2004, 279, 26243-26250.

13. Zarnegar, B.J.; Wang, Y.; Mahoney, D.J.; Dempsey, P.W.; Cheung, H.H.; He, J.; Shiba, T.; Yang, X.; Yeh, W.; Mak, T.W.; Korneluk, R.G.; Cheng, G. Noncanonical NF-кB activation requires coordinated assembly of a regulatory complex of the adaptors cIAP1, cIAP2, TRAF2 and TRAF3 and the kinase NIK. Nat. Immunol. 2008, 9, 1371-1378.

14. Vallabhapurapu, S.; Matsuzawa, A.; Zhang, W.; Tseng, P.; Keats, J.J.; Wang, H.; Vignali, D.A.A.; Bergsagel, P.L.; Karin, M. Nonredundant and complementary functions of TRAF2 and TRAF3 in a ubiquitination cascade that activates NIK-dependent alternative NF- $\kappa B$ signaling. Nat. Immunol. 2008, 9, 1364-1370.

15. Xiao, G.; Fong, A.; Sun, S. Induction of p100 processing by NF- $\kappa B$-inducing kinase involves docking IאB kinase $\alpha(\mathrm{IKK} \alpha)$ to $\mathrm{p} 100$ and IKK $\alpha$-mediated phosphorylation. J. Biol. Chem. 2004, 279, 30099-30105.

16. Derudder, E.; Dejardin, E.; Pritchard, L.L.; Green, D.R.; Korner, M.; Baud, V. RelB/p50 dimers are differentially regulated by tumor necrosis factor- $\alpha$ and lymphotoxin- $\beta$ receptor activation: Critical roles for p100. J. Biol. Chem. 2003, 278, 23278-23284.

17. Basak, S.; Kim, H.; Kearns, J.D.; Tergaonkar, V.; O'Dea, E.; Werner, S.L.; Benedict, C.A.; Ware, C.F.; Ghosh, G.; Verma, I.M.; Hoffmann, A. A fourth $\mathrm{I} \kappa \mathrm{B}$ protein within the NF- $\kappa \mathrm{B}$ signaling module. Cell 2007, 128, 369-381.

18. Dejardin, E.; Droin, N.M.; Delhase, M.; Haas, E.; Cao, Y.; Makris, C.; Li, Z.; Karin, M.; Ware, C.F.; Green, D.R. The lymphotoxin- $\beta$ receptor induces different patterns of gene expression via two NF-кB pathways. Immunity 2002, 17, 525-535.

19. Müller, J.R.; Siebenlist, U. Lymphotoxin $\beta$ receptor induces sequential activation of distinct NF$\kappa \mathrm{B}$ factors via separate signaling pathways. J. Biol. Chem. 2003, 278, 12006-12012.

20. Yilmaz, Z.B.; Weih, D.S.; Sivakumar, V.; Weih, F. RelB is required for Peyer's patch development: Differential regulation of p52-RelB by lymphotoxin and TNF. EMBO J. 2003, 22, 121-130.

21. Bren, G.D.; Solan, N.J.; Miyoshi, H.; Pennington, K.N.; Pobst, L.J.; Paya, C.V. Transcription of the RelB gene is regulated by NF-кB. Oncogene 2001, 20, 7722-7733.

22. Liptay, S.; Schmid, R.M.; Nabel, E.G.; Nabel, G.J. Transcriptional regulation of NF-кB2: Evidence for $\kappa \mathrm{B}$-mediated positive and negative autoregulation. Mol. Cell. Biol. 1994, 14, 7695-7703.

23. Basak, S.; Shih, V.F.; Hoffmann, A. Generation and activation of multiple dimeric transcription factors within the NF-кB signaling system. Mol. Cell. Biol. 2008, 28, 3139-3150.

24. Razani, B.; Zarnegar, B.; Ytterberg, A.J.; Shiba, T.; Dempsey, P.W.; Ware, C.F.; Loo, J.A.;

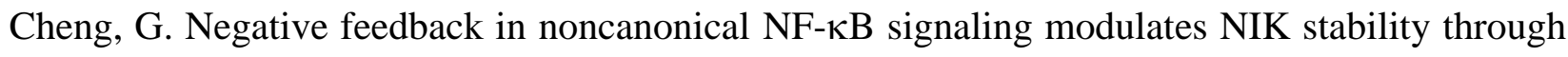
IKK $\alpha$-mediated phosphorylation. Sci. Signal. 2010, 3, ra41. 
25. Ramakrishnan, P.; Wang, W.; Wallach, D. Receptor-specific signaling for both the alternative

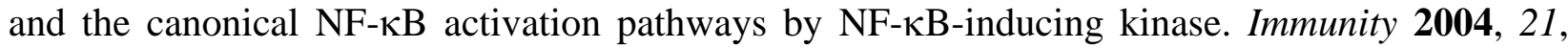
477-489.

26. Zarnegar, B.; Yamazaki, S.; He, J.Q.; Cheng, G. Control of canonical NF-кB activation through the NIK-IKK complex pathway. Proc. Natl. Acad. Sci. USA 2008, 105, 3503-3508.

27. Jost, P.J.; Ruland, J. Aberrant NF- $\mathrm{BB}$ signaling in lymphoma: Mechanisms, consequences, and therapeutic implications. Blood 2007, 109, 2700-2707.

28. Packham, G. The role of NF-אB in lymphoid malignancies. Br. J. Haematol. 2008, 143, 3-15.

29. Annunziata, C.M.; Davis, R.E.; Demchenko, Y.; Bellamy, W.; Gabrea, A.; Zhan, F.; Lenz, G.; Hanamura, I.; Wright, G.; Xiao, W.; Dave, S.; Hurt, E.M.; Tan, B.; Zhao, H.; Stephens, O.; Santra, M.; Williams, D.R.; Dang, L.; Barlogie, B.; Shaughnessy, J.D.; Kuehl, W.M.; Staudt, L.M. Frequent engagement of the classical and alternative NF- $\kappa \mathrm{B}$ pathways by diverse genetic abnormalities in multiple myeloma. Cancer Cell 2007, 12, 115-130.

30. Keats, J.J.; Fonseca, R.; Chesi, M.; Schop, R.; Baker, A.; Chng, W.; Van Wier, S.; Tiedemann, R.; Shi, C.; Sebag, M.; Braggio, E.; Henry, T.; Zhu, Y.; Fogle, H.; Price-Troska, T.; Ahmann, G.; Mancini, C.; Brents, L.A.; Kumar, S.; Greipp, P.; Dispenzieri, A.; Bryant, B.; Mulligan, G.; Bruhn, L.; Barrett, M.; Valdez, R.; Trent, J.; Stewart, A.K.; Carpten, J.; Bergsagel, P.L. Promiscuous mutations activate the noncanonical NF-kB pathway in multiple myeloma. Cancer Cell 2007, 12, 131-144.

31. Hideshima, T.; Neri, P.; Tassone, P.; Yasui, H.; Ishitsuka, K.; Raje, N.; Chauhan, D.; Podar, K.; Mitsiades, C.; Dang, L.; Munshi, N.; Richardson, P.; Schenkein, D.; Anderson, K.C. MLN120B, a novel I $\mathrm{B}$ kinase $\beta$ inhibitor, blocks multiple myeloma cell growth in vitro and in vivo. Clin. Cancer Res. 2006, 12, 5887-5894.

32. Compagno, M.; Lim, W.K.; Grunn, A.; Nandula, S.V.; Brahmachary, M.; Shen, Q.; Bertoni, F.; Ponzoni, M.; Scandurra, M.; Califano, A.; Bhagat, G.; Chadburn, A.; Dalla-Favera, R.; Pasqualucci, L. Mutations of multiple genes cause deregulation of NF- $\kappa \mathrm{B}$ in diffuse large B-cell lymphoma. Nature 2009, 459, 717-721.

33. Kato, M.; Sanada, M.; Kato, I.; Sato, Y.; Takita, J.; Takeuchi, K.; Niwa, A.; Chen, Y.; Nakazaki, K.; Nomoto, J.; Asakura, Y.; Muto, S.; Tamura, A.; Iio, M.; Akatsuka, Y.; Hayashi, Y.; Mori, H.; Igarashi, T.; Kurokawa, M.; Chiba, S.; Mori, S.; Ishikawa, Y.; Okamoto, K.; Tobinai, K.; Nakagama, H.; Nakahata, T.; Yoshino, T.; Kobayashi, Y.; Ogawa, S. Frequent inactivation of A20 in B-cell lymphomas. Nature 2009, 459, 712-716.

34. Lenz, G.; Davis, R.E.; Ngo, V.N.; Lam, L.; George, T.C.; Wright, G.W.; Dave, S.S.; Zhao, H.; $\mathrm{Xu}$, W.; Rosenwald, A.; Ott, G.; Muller-Hermelink, H.K.; Gascoyne, R.D.; Connors, J.M.; Rimsza, L.M.; Campo, E.; Jaffe, E.S.; Delabie, J.; Smeland, E.B.; Fisher, R.I.; Chan, W.C.; Staudt, L.M. Oncogenic CARD11 mutations in human diffuse large B cell lymphoma. Science 2008, 319, 1676-1679.

35. Horie, R.; Watanabe, T.; Morishita, Y.; Ito, K.; Ishida, T.; Kanegae, Y.; Saito, I.; Higashihara, M.; Mori, S.; Kadin, M.E.; Watanabe, T. Ligand-independent signaling by overexpressed CD30 drives NF-кB activation in Hodgkin-Reed-Sternberg cells. Oncogene 2002, 21, 2493-2503. 
36. Annunziata, C.M.; Safiran, Y.J.; Irving, S.G.; Kasid, U.N.; Cossman, J. Hodgkin disease: Pharmacologic intervention of the CD40-NF- $\kappa \mathrm{B}$ pathway by a protease inhibitor. Blood 2000, 96, 2841-2848.

37. Endo, T.; Nishio, M.; Enzler, T.; Cottam, H.B.; Fukuda, T.; James, D.F.; Karin, M.; Kipps, T.J. BAFF and APRIL support chronic lymphocytic leukemia B-cell survival through activation of the canonical NF-кB pathway. Blood 2007, 109, 703-710.

38. Moreaux, J.; Legouffe, E.; Jourdan, E.; Quittet, P.; Rème, T.; Lugagne, C.; Moine, P.; Rossi, J.; Klein, B.; Tarte, K. BAFF and APRIL protect myeloma cells from apoptosis induced by interleukin 6 deprivation and dexamethasone. Blood 2004, 103, 3148-3157.

39. Novak, A.J.; Grote, D.M.; Stenson, M.; Ziesmer, S.C.; Witzig, T.E.; Habermann, T.M.; Harder, B.; Ristow, K.M.; Bram, R.J.; Jelinek, D.F.; Gross, J.A.; Ansell, S.M. Expression of BLyS and its receptors in B-cell non-Hodgkin lymphoma: Correlation with disease activity and patient outcome. Blood 2004, 104, 2247-2253.

40. Cilloni, D.; Messa, F.; Arruga, F.; Defilippi, I.; Morotti, A.; Messa, E.; Carturan, S.; Giugliano, E.; Pautasso, M.; Bracco, E.; Rosso, V.; Sen, A.; Martinelli, G.; Baccarani, M.; Saglio, G. The NF- $\kappa$ B pathway blockade by the IKK inhibitor PS1145 can overcome imatinib resistance. Leukemia 2006, 20, 61-67.

41. Gatto, S.; Scappini, B.; Pham, L.; Onida, F.; Milella, M.; Ball, G.; Ricci, C.; Divoky, V.; Verstovsek, S.; Kantarjian, H.M.; Keating, M.J.; Cortes-Franco, J.E.; Beran, M. The proteasome inhibitor PS-341 inhibits growth and induces apoptosis in Bcr/Abl-positive cell lines sensitive and resistant to imatinib mesylate. Haematologica 2003, 88, 853-863.

42. Duncan, E.A.; Goetz, C.A.; Stein, S.J.; Mayo, K.J.; Skaggs, B.J.; Ziegelbauer, K.; Sawyers, C.L.; Baldwin, A.S. I $\mathrm{B}$ kinase $\beta$ inhibition induces cell death in Imatinib-resistant and T315I Dasatinib-resistant BCR-ABL ${ }^{+}$cells. Mol. Cancer Ther. 2008, 7, 391-397.

43. Besançon, F.; Atfi, A.; Gespach, C.; Cayre, Y.E.; Bourgeade, M.F. Evidence for a role of NF-кB in the survival of hematopoietic cells mediated by interleukin 3 and the oncogenic TEL/plateletderived growth factor receptor $\beta$ fusion protein. Proc. Natl. Acad. Sci. USA 1998, 95, 8081-8086.

44. Han, X.; Bueso-Ramos, C.E. Precursor T-cell acute lymphoblastic leukemia/lymphoblastic lymphoma and acute biphenotypic leukemias. Am. J. Clin. Pathol. 2007, 127, 528-544.

45. Schraders, M.; van Reijmersdal, S.V.; Kamping, E.J.; van Krieken, J.H.J.M.; van Kessel, A.G.; Groenen, P.J.T.A.; Hoogerbrugge, P.M.; Kuiper, R.P. High-resolution genomic profiling of pediatric lymphoblastic lymphomas reveals subtle differences with pediatric acute lymphoblastic leukemias in the B-lineage. Cancer Genet. Cytogenet 2009, 191, 27-33.

46. De Keersmaecker, K.; Marynen, P.; Cools, J. Genetic insights in the pathogenesis of T-cell acute lymphoblastic leukemia. Haematologica 2005, 90, 1116-1127.

47. Aifantis, I.; Raetz, E.; Buonamici, S. Molecular pathogenesis of T-cell leukaemia and lymphoma. Nat. Rev. Immunol. 2008, 8, 380-390.

48. Graux, C.; Cools, J.; Michaux, L.; Vandenberghe, P.; Hagemeijer, A. Cytogenetics and molecular genetics of T-cell acute lymphoblastic leukemia: From thymocyte to lymphoblast. Leukemia 2006, 20, 1496-1510.

49. Van Vlierberghe, P.; Pieters, R.; Beverloo, H.B.; Meijerink, J.P.P. Molecular-genetic insights in paediatric T-cell acute lymphoblastic leukaemia. Br. J. Haematol. 2008, 143, 153-168. 
50. Weng, A.P.; Ferrando, A.A.; Lee, W.; Morris, J.P.; Silverman, L.B.; Sanchez-Irizarry, C.; Blacklow, S.C.; Look, A.T.; Aster, J.C. Activating mutations of NOTCH1 in human T cell acute lymphoblastic leukemia. Science 2004, 306, 269-271.

51. Cayuela, J.M.; Madani, A.; Sanhes, L.; Stern, M.H.; Sigaux, F. Multiple tumor-suppressor gene 1 inactivation is the most frequent genetic alteration in T-cell acute lymphoblastic leukemia. Blood 1996, 87, 2180-2186.

52. Flex, E.; Petrangeli, V.; Stella, L.; Chiaretti, S.; Hornakova, T.; Knoops, L.; Ariola, C.; Fodale, V.; Clappier, E.; Paoloni, F.; Martinelli, S.; Fragale, A.; Sanchez, M.; Tavolaro, S.; Messina, M.; Cazzaniga, G.; Camera, A.; Pizzolo, G.; Tornesello, A.; Vignetti, M.; Battistini, A.; Cavé, H.; Gelb, B.D.; Renauld, J.; Biondi, A.; Constantinescu, S.N.; Foà, R.; Tartaglia, M. Somatically acquired JAK1 mutations in adult acute lymphoblastic leukemia. J. Exp. Med. 2008, 205, 751-758.

53. Yokota, S.; Nakao, M.; Horiike, S.; Seriu, T.; Iwai, T.; Kaneko, H.; Azuma, H.; Oka, T.; Takeda, T.; Watanabe, A.; Kikuta, A.; Asami, K.; Sekine, I.; Matsushita, T.; Tsuhciya, T.; Mimaya, J.; Koizumi, S.; Miyake, M.; Nishikawa, K.; Takaue, Y.; Kawano, Y.; Iwai, A.; Ishida, Y.; Matsumoto, K.; Fujimoto, T. Mutational analysis of the N-ras gene in acute lymphoblastic leukemia: A study of 125 Japanese pediatric cases. Int. J. Hematol. 1998, 67, 379-387.

54. Paietta, E.; Ferrando, A.A.; Neuberg, D.; Bennett, J.M.; Racevskis, J.; Lazarus, H.; Dewald, G.; Rowe, J.M.; Wiernik, P.H.; Tallman, M.S.; Look, A.T. Activating FLT3 mutations in CD117/KIT ${ }^{+}$T-cell acute lymphoblastic leukemias. Blood 2004, 104, 558-560.

55. Graux, C.; Cools, J.; Melotte, C.; Quentmeier, H.; Ferrando, A.; Levine, R.; Vermeesch, J.R.; Stul, M.; Dutta, B.; Boeckx, N.; Bosly, A.; Heimann, P.; Uyttebroeck, A.; Mentens, N.; Somers, R.; MacLeod, R.A.F.; Drexler, H.G.; Look, A.T.; Gilliland, D.G.; Michaux, L.; Vandenberghe, P.; Wlodarska, I.; Marynen, P.; Hagemeijer, A. Fusion of NUP214 to ABL1 on amplified episomes in T-cell acute lymphoblastic leukemia. Nat. Genet. 2004, 36, 1084-1089.

56. Clappier, E.; Cuccuini, W.; Kalota, A.; Crinquette, A.; Cayuela, J.; Dik, W.A.; Langerak, A.W.; Montpellier, B.; Nadel, B.; Walrafen, P.; Delattre, O.; Aurias, A.; Leblanc, T.; Dombret, H.; Gewirtz, A.M.; Baruchel, A.; Sigaux, F.; Soulier, J. The C-MYB locus is involved in chromosomal translocation and genomic duplications in human T-cell acute leukemia (T-ALL), the translocation defining a new T-ALL subtype in very young children. Blood 2007, 110, 1251-1261.

57. Lahortiga, I.; De Keersmaecker, K.; Van Vlierberghe, P.; Graux, C.; Cauwelier, B.; Lambert, F.; Mentens, N.; Beverloo, H.B.; Pieters, R.; Speleman, F.; Odero, M.D.; Bauters, M.; Froyen, G.; Marynen, P.; Vandenberghe, P.; Wlodarska, I.; Meijerink, J.P.P.; Cools, J. Duplication of the MYB oncogene in T cell acute lymphoblastic leukemia. Nat. Genet. 2007, 39, 593-595.

58. O'Neil, J.; Grim, J.; Strack, P.; Rao, S.; Tibbitts, D.; Winter, C.; Hardwick, J.; Welcker, M.; Meijerink, J.P.; Pieters, R.; Draetta, G.; Sears, R.; Clurman, B.E.; Look, A.T. FBW7 mutations in leukemic cells mediate NOTCH pathway activation and resistance to $\gamma$-secretase inhibitors. $J$. Exp. Med. 2007, 204, 1813-1824.

59. Silva, A.; Yunes, J.A.; Cardoso, B.A.; Martins, L.R.; Jotta, P.Y.; Abecasis, M.; Nowill, A.E.; Leslie, N.R.; Cardoso, A.A.; Barata, J.T. PTEN posttranslational inactivation and hyperactivation 
of the PI3K/Akt pathway sustain primary T cell leukemia viability. J. Clin. Invest. 2008, 118, 3762-3774.

60. Palomero, T.; Sulis, M.L.; Cortina, M.; Real, P.J.; Barnes, K.; Ciofani, M.; Caparros, E.; Buteau, J.; Brown, K.; Perkins, S.L.; Bhagat, G.; Agarwal, A.M.; Basso, G.; Castillo, M.; Nagase, S.; Cordon-Cardo, C.; Parsons, R.; Zúñiga-Pflücker, J.C.; Dominguez, M.; Ferrando, A.A. Mutational loss of PTEN induces resistance to NOTCH1 inhibition in T-cell leukemia. Nat. Med. 2007, 13, 1203-1210.

61. Gutierrez, A.; Tschumper, R.C.; Wu, X.; Shanafelt, T.D.; Eckel-Passow, J.; Huddleston, P.M.; Slager, S.L.; Kay, N.E.; Jelinek, D.F. LEF-1 is a prosurvival factor in chronic lymphocytic leukemia and is expressed in the preleukemic state of monoclonal B cell lymphocytosis. Blood 2010, 115, 2845-2851.

62. Kleppe, M.; Lahortiga, I.; El Chaar, T.; De Keersmaecker, K.; Mentens, N.; Graux, C.; Van Roosbroeck, K.; Ferrando, A.A.; Langerak, A.W.; Meijerink, J.P.P.; Sigaux, F.; Haferlach, T.; Wlodarska, I.; Vandenberghe, P.; Soulier, J.; Cools, J. Deletion of the protein tyrosine phosphatase gene PTPN2 in T-cell acute lymphoblastic leukemia. Nat. Genet. 2010, 42, 530-535.

63. Van Vlierberghe, P.; Palomero, T.; Khiabanian, H.; Van der Meulen, J.; Castillo, M.; Van Roy, N.; De Moerloose, B.; Philippé, J.; González-García, S.; Toribio, M.L.; Taghon, T.; Zuurbier, L.; Cauwelier, B.; Harrison, C.J.; Schwab, C.; Pisecker, M.; Strehl, S.; Langerak, A.W.; Gecz, J.; Sonneveld, E.; Pieters, R.; Paietta, E.; Rowe, J. M.; Wiernik, P.H.; Benoit, Y.; Soulier, J.; Poppe, B.; Yao, X.; Cordon-Cardo, C.; Meijerink, J.; Rabadan, R.; Speleman, F.; Ferrando, A. PHF6 mutations in T-cell acute lymphoblastic leukemia. Nat. Genet. 2010, 42, 338-342.

64. Cardoso, B.A.; Gírio, A.; Henriques, C.; Martins, L.R.; Santos, C.; Silva, A.; Barata, J.T. Aberrant signaling in T-cell acute lymphoblastic leukemia: Biological and therapeutic implications. Braz. J. Med. Biol. Res. 2008, 41, 344-350.

65. Staal, F.J.T.; Langerak, A.W. Signaling pathways involved in the development of T-cell acute lymphoblastic leukemia. Haematologica 2008, 93, 493-497.

66. Kordes, U.; Krappmann, D.; Heissmeyer, V.; Ludwig, W.D.; Scheidereit, C. Transcription factor $\mathrm{NF}-\kappa \mathrm{B}$ is constitutively activated in acute lymphoblastic leukemia cells. Leukemia 2000, 14, 399-402.

67. Vilimas, T.; Mascarenhas, J.; Palomero, T.; Mandal, M.; Buonamici, S.; Meng, F.; Thompson, B.; Spaulding, C.; Macaroun, S.; Alegre, M.; Kee, B.L.; Ferrando, A.; Miele, L.; Aifantis, I. Targeting the NF- $\mathrm{KB}$ signaling pathway in Notch1-induced T-cell leukemia. Nat. Med. 2007, 13, 70-77.

68. Bellavia, D.; Campese, A.F.; Alesse, E.; Vacca, A.; Felli, M.P.; Balestri, A.; Stoppacciaro, A.; Tiveron, C.; Tatangelo, L.; Giovarelli, M.; Gaetano, C.; Ruco, L.; Hoffman, E.S.; Hayday, A.C.;

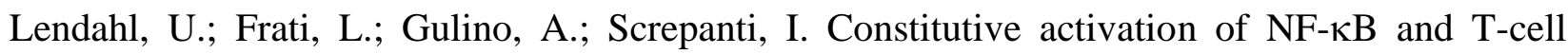
leukemia/lymphoma in Notch3 transgenic mice. EMBO J. 2000, 19, 3337-3348.

69. dos Santos, N.R.; Williame, M.; Gachet, S.; Cormier, F.; Janin, A.; Weih, D.; Weih, F.; Ghysdael, J. RelB-dependent stromal cells promote T-cell leukemogenesis. PLoS ONE 2008, 3, e2555.

70. O'Neil, J.; Ventura, J.; Cusson, N.; Kelliher, M. NF-кB activation in premalignant mouse tal-1/scl thymocytes and tumors. Blood 2003, 102, 2593-2596. 
71. Espinosa, L.; Cathelin, S.; D'Altri, T.; Trimarchi, T.; Statnikov, A.; Guiu, J.; Rodilla, V.; InglésEsteve, J.; Nomdedeu, J.; Bellosillo, B.; Besses, C.; Abdel-Wahab, O.; Kucine, N.; Sun, S.; Song, G.; Mullighan, C.C.; Levine, R.L.; Rajewsky, K.; Aifantis, I.; Bigas, A. The Notch/Hes1 pathway sustains NF- $\mathrm{KB}$ activation through $C Y L D$ repression in $\mathrm{T}$ cell leukemia. Cancer Cell 2010, 18, 268-281.

72. García, M.G.; Alaniz, L.; Lopes, E.C.; Blanco, G.; Hajos, S.E.; Alvarez, E. Inhibition of NF-кB activity by BAY 11-7082 increases apoptosis in multidrug resistant leukemic T-cell lines. Leuk. Res. 2005, 29, 1425-1434.

73. Karin, M. The IкB kinase - a bridge between inflammation and cancer. Cell Res. 2008, 18, 334-342.

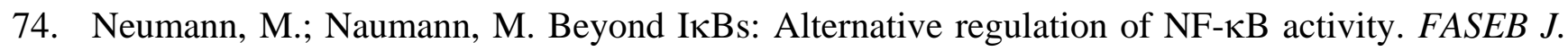
2007, 21, 2642-2654.

75. Jamieson, C.; McCaffrey, P.G.; Rao, A.; Sen, R. Physiologic activation of $\mathrm{T}$ cells via the $\mathrm{T}$ cell receptor induces NF-кB. J. Immunol. 1991, 147, 416-420.

76. Aifantis, I.; Gounari, F.; Scorrano, L.; Borowski, C.; von Boehmer, H. Constitutive pre-TCR signaling promotes differentiation through $\mathrm{Ca}^{+}$mobilization and activation of $\mathrm{NF}-\kappa \mathrm{B}$ and NFAT. Nat. Immunol. 2001, 2, 403-409.

77. Voll, R.E.; Jimi, E.; Phillips, R.J.; Barber, D.F.; Rincon, M.; Hayday, A.C.; Flavell, R.A.; Ghosh, $\mathrm{S}$. NF- $\kappa \mathrm{B}$ activation by the pre-T cell receptor serves as a selective survival signal in $\mathrm{T}$ lymphocyte development. Immunity 2000, 13, 677-689.

78. Rawlings, D.J.; Sommer, K.; Moreno-García, M.E. The CARMA1 signalosome links the signalling machinery of adaptive and innate immunity in lymphocytes. Nat. Rev. Immunol. 2006, 6, 799-812.

79. Akagi, T.; Motegi, M.; Tamura, A.; Suzuki, R.; Hosokawa, Y.; Suzuki, H.; Ota, H.; Nakamura, S.; Morishima, Y.; Taniwaki, M.; Seto, M. A novel gene, MALT1 at 18q21, is involved in $\mathrm{t}(11 ; 18)$ (q21;q21) found in low-grade B-cell lymphoma of mucosa-associated lymphoid tissue. Oncogene 1999, 18, 5785-5794.

80. Dierlamm, J.; Baens, M.; Wlodarska, I.; Stefanova-Ouzounova, M.; Hernandez, J.M.; Hossfeld, D.K.; De Wolf-Peeters, C.; Hagemeijer, A.; Van den Berghe, H.; Marynen, P. The apoptosis inhibitor gene $A P I 2$ and a novel $18 \mathrm{q}$ gene, $M L T$, are recurrently rearranged in the $\mathrm{t}(11 ; 18)(\mathrm{q} 21 ; \mathrm{q} 21)$ associated with mucosa-associated lymphoid tissue lymphomas. Blood 1999, 93, 3601-3609.

81. Strzadala, L.; Miazek, A.; Matuszyk, J.; Kisielow, P. Role of thymic selection in the development of thymic lymphomas in TCR transgenic mice. Int. Immunol. 1997, 9, 127-138.

82. Davis, R.E.; Ngo, V.N.; Lenz, G.; Tolar, P.; Young, R.M.; Romesser, P.B.; Kohlhammer, H.; Lamy, L.; Zhao, H.; Yang, Y.; Xu, W.; Shaffer, A.L.; Wright, G.; Xiao, W.; Powell, J.; Jiang, J.; Thomas, C.J.; Rosenwald, A.; Ott, G.; Muller-Hermelink, H.K.; Gascoyne, R.D.; Connors, J.M.; Johnson, N.A.; Rimsza, L.M.; Campo, E.; Jaffe, E.S.; Wilson, W.H.; Delabie, J.; Smeland, E.B.; Fisher, R.I.; Braziel, R.M.; Tubbs, R.R.; Cook, J.R.; Weisenburger, D.D.; Chan, W.C.; Pierce, S.K.; Staudt, L.M. Chronic active B-cell-receptor signalling in diffuse large B-cell lymphoma. Nature 2010, 463, 88-92. 
83. Asnafi, V.; Beldjord, K.; Boulanger, E.; Comba, B.; Le Tutour, P.; Estienne, M.; Davi, F.; Landman-Parker, J.; Quartier, P.; Buzyn, A.; Delabesse, E.; Valensi, F.; Macintyre, E. Analysis of TCR, pT $\alpha$, and RAG-1 in T-acute lymphoblastic leukemias improves understanding of early human T-lymphoid lineage commitment. Blood 2003, 101, 2693-2703.

84. Burger, R.; Hansen-Hagge, T.E.; Drexler, H.G.; Gramatzki, M. Heterogeneity of T-acute lymphoblastic leukemia (T-ALL) cell lines: Suggestion for classification by immunophenotype and T-cell receptor studies. Leuk. Res. 1999, 23, 19-27.

85. Vacca, A.; Felli, M.P.; Palermo, R.; Di Mario, G.; Calce, A.; Di Giovine, M.; Frati, L.; Gulino, A.; Screpanti, I. Notch3 and pre-TCR interaction unveils distinct Dierlamm, J.; Baens, M pathways in T-cell development and leukemia. EMBO J. 2006, 25, 1000-1008.

86. Palomero, T.; Lim, W.K.; Odom, D.T.; Sulis, M.L.; Real, P.J.; Margolin, A.; Barnes, K.C.; O'Neil, J.; Neuberg, D.; Weng, A.P.; Aster, J.C.; Sigaux, F.; Soulier, J.; Look, A.T.; Young, R.A.; Califano, A.; Ferrando, A.A. NOTCH1 directly regulates c-MYC and activates a feed-forwardloop transcriptional network promoting leukemic cell growth. Proc. Natl. Acad. Sci. USA 2006, 103, 18261-18266.

87. Osipo, C.; Golde, T.E.; Osborne, B.A.; Miele, L.A. Off the beaten pathway: The complex cross talk between Notch and NF-кB. Lab. Invest. 2008, 88, 11-17.

88. Oswald, F.; Liptay, S.; Adler, G.; Schmid, R.M. NF-кB2 is a putative target gene of activated Notch-1 via RBP-Jк. Mol. Cell. Biol. 1998, 18, 2077-2088.

89. Shin, H.M.; Minter, L.M.; Cho, O.H.; Gottipati, S.; Fauq, A.H.; Golde, T.E.; Sonenshein, G.E.; Osborne, B.A. Notch1 augments NF-kB activity by facilitating its nuclear retention. EMBO J. 2006, 25, 129-138.

90. Song, L.L.; Peng, Y.; Yun, J.; Rizzo, P.; Chaturvedi, V.; Weijzen, S.; Kast, W.M.; Stone, P.J.B.; Santos, L.; Loredo, A.; Lendahl, U.; Sonenshein, G.; Osborne, B.; Qin, J.; Pannuti, A.; Nickoloff, B.J.; Miele, L. Notch-1 associates with IKK $\alpha$ and regulates IKK activity in cervical cancer cells. Oncogene 2008, 27, 5833-5844.

91. Chang, P.; Draheim, K.; Kelliher, M.A.; Miyamoto, S. NFKB1 is a direct target of the TAL1 oncoprotein in human T leukemia cells. Cancer Res. 2006, 66, 6008-6013.

92. Carron, C.; Cormier, F.; Janin, A.; Lacronique, V.; Giovannini, M.; Daniel, M.T.; Bernard, O.; Ghysdael, J. TEL-JAK2 transgenic mice develop T-cell leukemia. Blood 2000, 95, 3891-3899.

93. dos Santos, N.R.; Ghysdael, J. A transgenic mouse model for TEL-JAK2-induced B-cell lymphoma/leukemia. Leukemia 2006, 20, 182-185.

94. Lacronique, V.; Boureux, A.; Valle, V.D.; Poirel, H.; Quang, C.T.; Mauchauffé, M.; Berthou, C.; Lessard, M.; Berger, R.; Ghysdael, J.; Bernard, O.A. A TEL-JAK2 fusion protein with constitutive kinase activity in human leukemia. Science 1997, 278, 1309-1312.

95. Peeters, P.; Raynaud, S.D.; Cools, J.; Wlodarska, I.; Grosgeorge, J.; Philip, P.; Monpoux, F.; Van Rompaey, L.; Baens, M.; Van den Berghe, H.; Marynen, P. Fusion of TEL, the ETS-variant gene 6 (ETV6), to the receptor-associated kinase $J A K 2$ as a result of $\mathrm{t}(9 ; 12)$ in a lymphoid and $\mathrm{t}(9 ; 15 ; 12)$ in a myeloid leukemia. Blood 1997, 90, 2535-2540.

96. Schwaller, J.; Frantsve, J.; Aster, J.; Williams, I.R.; Tomasson, M.H.; Ross, T.S.; Peeters, P.; Van Rompaey, L.; Van Etten, R.A.; Ilaria, R.; Marynen, P.; Gilliland, D.G. Transformation of hematopoietic cell lines to growth-factor independence and induction of a fatal myelo- and 
lymphoproliferative disease in mice by retrovirally transduced TEL/JAK2 fusion genes. EMBO J. 1998, 17, 5321-5333.

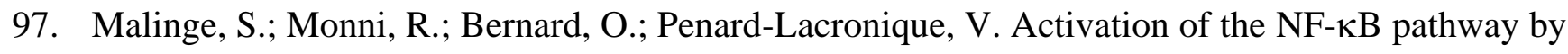
the leukemogenic TEL-Jak2 and TEL-Abl fusion proteins leads to the accumulation of antiapoptotic IAP proteins and involves IKKa. Oncogene 2006, 25, 3589-3597.

98. Santos, S.C.; Monni, R.; Bouchaert, I.; Bernard, O.; Gisselbrecht, S.; Gouilleux, F.; PenardLacronique, V. Involvement of the NF- $\mathrm{BB}$ pathway in the transforming properties of the TELJak2 leukemogenic fusion protein. FEBS Lett. 2001, 497, 148-152.

99. Burnett, R.C.; Thirman, M.J.; Rowley, J.D.; Diaz, M.O. Molecular analysis of the T-cell acute lymphoblastic leukemia-associated $\mathrm{t}(1 ; 7)(\mathrm{p} 34 ; \mathrm{q} 34)$ that fuses $L C K$ and TCRB. Blood 1994, 84, 1232-1236.

100. Livolsi, A.; Busuttil, V.; Imbert, V.; Abraham, R.T.; Peyron, J.F. Tyrosine phosphorylationdependent activation of NF- $\kappa \mathrm{B}$. Requirement for p56 LCK and ZAP-70 protein tyrosine kinases. Eur. J. Biochem. 2001, 268, 1508-1515.

101. Hamdane, M.; David-Cordonnier, M.H.; D'Halluin, J.C. Activation of p65 NF- $\kappa$ B protein by $\mathrm{p} 210^{\mathrm{BCR}-\mathrm{ABL}}$ in a myeloid cell line $\left(\mathrm{P} 210^{\mathrm{BCR}-\mathrm{ABL}}\right.$ activates p65 NF- $\left.\mathrm{\kappa B}\right)$. Oncogene 1997, 15, 22672275.

102. Reuther, J.Y.; Reuther, G.W.; Cortez, D.; Pendergast, A.M.; Baldwin, A.S. A requirement for NF- $\kappa$ B activation in Bcr-Abl-mediated transformation. Genes Dev. 1998, 12, 968-981.

103. Narayan, P.; Holt, B.; Tosti, R.; Kane, L.P. CARMA1 is required for Akt-mediated NF-кB activation in T cells. Mol. Cell. Biol 2006, 26, 2327-2336.

104. Garaude, J.; Cherni, S.; Kaminski, S.; Delepine, E.; Chable-Bessia, C.; Benkirane, M.; Borges, J.; Pandiella, A.; Iñiguez, M.A.; Fresno, M.; Hipskind, R.A.; Villalba, M. ERK5 activates NF-кB in leukemic $\mathrm{T}$ cells and is essential for their growth in vivo. J. Immunol. 2006, 177, 7607-7617.

105. Tlsty, T.D.; Coussens, L.M. Tumor stroma and regulation of cancer development. Annu. Rev. Pathol. 2006, 1, 119-150.

106. Herreros, B.; Sanchez-Aguilera, A.; Piris, M.A. Lymphoma microenvironment: Culprit or innocent? Leukemia 2008, 22, 49-58.

107. dos Santos, N.R.; Rickman, D.S.; de Reynies, A.; Cormier, F.; Williame, M.; Blanchard, C.; Stern, M.H.; Ghysdael, J. Pre-TCR expression cooperates with TEL-JAK2 to transform immature thymocytes and induce T-cell leukemia. Blood 2007, 109, 3972-3981.

108. Burkly, L.; Hession, C.; Ogata, L.; Reilly, C.; Marconi, L.A.; Olson, D.; Tizard, R.; Cate, R.; Lo, D. Expression of $\mathrm{relB}$ is required for the development of thymic medulla and dendritic cells. Nature 1995, 373, 531-536.

109. Gray, D.H.D.; Seach, N.; Ueno, T.; Milton, M.K.; Liston, A.; Lew, A.M.; Goodnow, C.C.; Boyd, R.L. Developmental kinetics, turnover, and stimulatory capacity of thymic epithelial cells. Blood 2006, 108, 3777-3785.

110. Weih, F.; Carrasco, D.; Durham, S.K.; Barton, D.S.; Rizzo, C.A.; Ryseck, R.P.; Lira, S.A.; Bravo, R. Multiorgan inflammation and hematopoietic abnormalities in mice with a targeted disruption of RelB, a member of the NF- $\mathrm{BB} /$ Rel family. Cell 1995, 80, 331-340. 
111. Wu, L.; D'Amico, A.; Winkel, K.D.; Suter, M.; Lo, D.; Shortman, K. RelB is essential for the development of myeloid-related $\mathrm{CD} 8 \alpha^{-}$dendritic cells but not of lymphoid-related CD8 $\alpha^{+}$ dendritic cells. Immunity 1998, 9, 839-847.

112. Bonizzi, G.; Bebien, M.; Otero, D.C.; Johnson-Vroom, K.E.; Cao, Y.; Vu, D.; Jegga, A.G.; Aronow, B.J.; Ghosh, G.; Rickert, R.C.; Karin, M. Activation of IKK $\alpha$ target genes depends on recognition of specific $\kappa \mathrm{B}$ binding sites by RelB:p52 dimers. EMBO J. 2004, 23, 4202-4210.

113. Buonamici, S.; Trimarchi, T.; Ruocco, M.G.; Reavie, L.; Cathelin, S.; Mar, B.G.; Klinakis, A.; Lukyanov, Y.; Tseng, J.; Sen, F.; Gehrie, E.; Li, M.; Newcomb, E.; Zavadil, J.; Meruelo, D.; Lipp, M.; Ibrahim, S.; Efstratiadis, A.; Zagzag, D.; Bromberg, J.S.; Dustin, M.L.; Aifantis, I. CCR7 signalling as an essential regulator of CNS infiltration in T-cell leukaemia. Nature 2009, 459, 1000-1004.

114. Scupoli, M.T.; Vinante, F.; Krampera, M.; Vincenzi, C.; Nadali, G.; Zampieri, F.; Ritter, M.A.; Eren, E.; Santini, F.; Pizzolo, G. Thymic epithelial cells promote survival of human T-cell acute lymphoblastic leukemia blasts: The role of interleukin-7. Haematologica 2003, 88, 1229-1237.

115. Scupoli, M.T.; Perbellini, O.; Krampera, M.; Vinante, F.; Cioffi, F.; Pizzolo, G. Interleukin 7 requirement for survival of T-cell acute lymphoblastic leukemia and human thymocytes on bone marrow stroma. Haematologica 2007, 92, 264-266.

116. Indraccolo, S.; Minuzzo, S.; Masiero, M.; Pusceddu, I.; Persano, L.; Moserle, L.; Reboldi, A.; Favaro, E.; Mecarozzi, M.; Di Mario, G.; Screpanti, I.; Ponzoni, M.; Doglioni, C.; Amadori, A. Cross-talk between tumor and endothelial cells involving the Notch3-Dll4 interaction marks escape from tumor dormancy. Cancer Res. 2009, 69, 1314-1323.

117. Yan, X.Q.; Sarmiento, U.; Sun, Y.; Huang, G.; Guo, J.; Juan, T.; Van, G.; Qi, M.Y.; Scully, S.; Senaldi, G.; Fletcher, F.A. A novel Notch ligand, Dll4, induces T-cell leukemia/lymphoma when overexpressed in mice by retroviral-mediated gene transfer. Blood 2001, 98, 3793-3799.

118. Pui, C.; Robison, L.L.; Look, A.T. Acute lymphoblastic leukaemia. Lancet 2008, 371, 10301043.

119. Hannun, Y.A. Apoptosis and the dilemma of cancer chemotherapy. Blood 1997, 89, 1845-1853.

120. Das, K.C.; White, C.W. Activation of NF- $\kappa$ B by antineoplastic agents. Role of protein kinase C. J. Biol. Chem. 1997, 272, 14914-14920.

121. Nakanishi, C.; Toi, M. Nuclear factor- $\kappa \mathrm{B}$ inhibitors as sensitizers to anticancer drugs. Nat. Rev. Cancer 2005, 5, 297-309.

122. Baldwin, A.S. Control of oncogenesis and cancer therapy resistance by the transcription factor NF-кB. J. Clin. Invest. 2001, 107, 241-246.

123. Wuerzberger-Davis, S.M.; Chang, P.; Berchtold, C.; Miyamoto, S. Enhanced G2-M arrest by

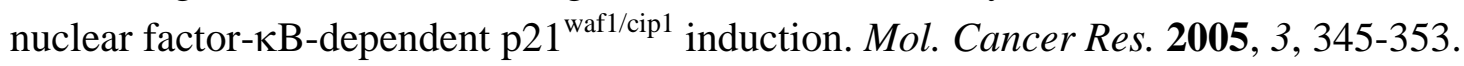

124. Chiarini, F.; Falà, F.; Tazzari, P.L.; Ricci, F.; Astolfi, A.; Pession, A.; Pagliaro, P.; McCubrey, J.A.; Martelli, A.M. Dual inhibition of class IA phosphatidylinositol 3-kinase and mammalian target of rapamycin as a new therapeutic option for T-cell acute lymphoblastic leukemia. Cancer Res. 2009, 69, 3520-3528.

125. Cullion, K.; Draheim, K.M.; Hermance, N.; Tammam, J.; Sharma, V.M.; Ware, C.; Nikov, G.; Krishnamoorthy, V.; Majumder, P.K.; Kelliher, M.A. Targeting the Notch1 and mTOR pathways in a mouse T-ALL model. Blood 2009, 113, 6172-6181. 
126. Moellering, R.E.; Cornejo, M.; Davis, T.N.; Del Bianco, C.; Aster, J.C.; Blacklow, S.C.; Kung, A.L.; Gilliland, D.G.; Verdine, G.L.; Bradner, J.E. Direct inhibition of the NOTCH transcription factor complex. Nature 2009, 462, 182-188.

127. Qiuping, Z.; Jei, X.; Youxin, J.; Wei, J.; Chun, L.; Jin, W.; Qun, W.; Yan, L.; Chunsong, H.; Mingzhen, Y.; Qingping, G.; Kejian, Z.; Zhimin, S.; Qun, L.; Junyan, L.; Jinquan, T. CC chemokine ligand 25 enhances resistance to apoptosis in $\mathrm{CD}^{+} \mathrm{T}$ cells from patients with $\mathrm{T}$-cell lineage acute and chronic lymphocytic leukemia by means of livin activation. Cancer Res. 2004, 64, 7579-7587.

128. Crazzolara, R.; Kreczy, A.; Mann, G.; Heitger, A.; Eibl, G.; Fink, F.M.; Möhle, R.; Meister, B. High expression of the chemokine receptor CXCR4 predicts extramedullary organ infiltration in childhood acute lymphoblastic leukaemia. Br. J. Haematol. 2001, 115, 545-553.

129. Winter, S.S.; Sweatman, J.J.; Lawrence, M.B.; Rhoades, T.H.; Hart, A.L.; Larson, R.S. Enhanced T-lineage acute lymphoblastic leukaemia cell survival on bone marrow stroma requires involvement of LFA-1 and ICAM-1. Br. J. Haematol. 2001, 115, 862-871.

(C) 2010 by the authors; licensee MDPI, Basel, Switzerland. This article is an open access article distributed under the terms and conditions of the Creative Commons Attribution license (http://creativecommons.org/licenses/by/3.0/). 